\title{
SEGUNDO CONGRESO NACIONAL DE MAGISTRADOS DEL PODER JUDICIAL
}

\author{
Arequipa 6,7 y 8 de noviembre de 2008 \\ DECLARACIÓN DE AREQUIPA
}

Los señores magistrados y servidores del Poder Judicial, participantes en el II Congreso Nacional de Magistrados del Poder Judicial, realizado en la ciudad de Arequipa, del 6 al 8 de noviembre de 2008, expresamos a la opinión pública:

Primero.- Respaldar las acciones realizadas por la Presidencia del Poder Judicial, la Sala Plena de la Corte Suprema de Justicia de la República y del Consejo Ejecutivo del Poder Judicial, en el marco del proceso de reforma judicial y de la implementación del nuevo Código Procesal Penal.

Segundo.- Luchar por el respecto a la autonomía del Poder Judicial e independencia de los magistrados en el ejercicio de su función jurisdiccional.

Tercero.- Aprovechar el acuerdo de la Sala Plena de la Corte Suprema de Justicia de la República respecto a la Ley de Carrera Judicial. La magistratura no se opone a la evaluación con fines de superación y capacitación, por el contrario ha contribuido a crear espacios para su debate y aplicación, dentro del respeto a los principios y valores constitucionales.

Cuarto.- Reconocer la importancia y necesidad de continuar aplicando políticas de implementación de la tecnología en la judicatura nacional, que permitan en un futuro próximo adoptar la oralidad en todo tipo de procesos judiciales, dentro del marco de nuestra inserción en la sociedad del conocimiento.

Quinto.- Apoyar la implementación de un diseño de Despacho Judicial con separación de las funciones administrativas y jurisdiccionales, utilizando para ello infraestructura y medios tecnológicos adecuados.

Sexto.- Ratificar el acuerdo de institucionalización de los Congresos Nacionales de Magistrados. En ese sentido, se deberán realizar las acciones necesarias para segurar la efectividad de un próximo III Congreso Nacional de la judicatura peruana. 
Séptimo.- Felicitar a los máximos órganos de gobierno del Poder Judicial y a la Comisión Organizadora de este evento, por el éxito del II Congreso Nacional de Magistrados.

Octavo.- Saludar a la muy notable y muy leal ciudad de Arequipa, sede de este II Congreso Nacional de Magistrados del Poder Judicial, por su cálida acogida.

Noveno.- Reconocer la importancia de afirmar una cultura organizacional del Poder Judicial y dentro de ello salud ar la creación del Himno del Poder Judicial, recientemente aprobado, aporte valioso que los magistrados felicitan.

Décimo.- Afirmar nuestro compromiso categórico de ejercer la magistratura con imparcialidad, y respeto a la Constitución, en aras del desarrollo del país.

Siguen firmas. 


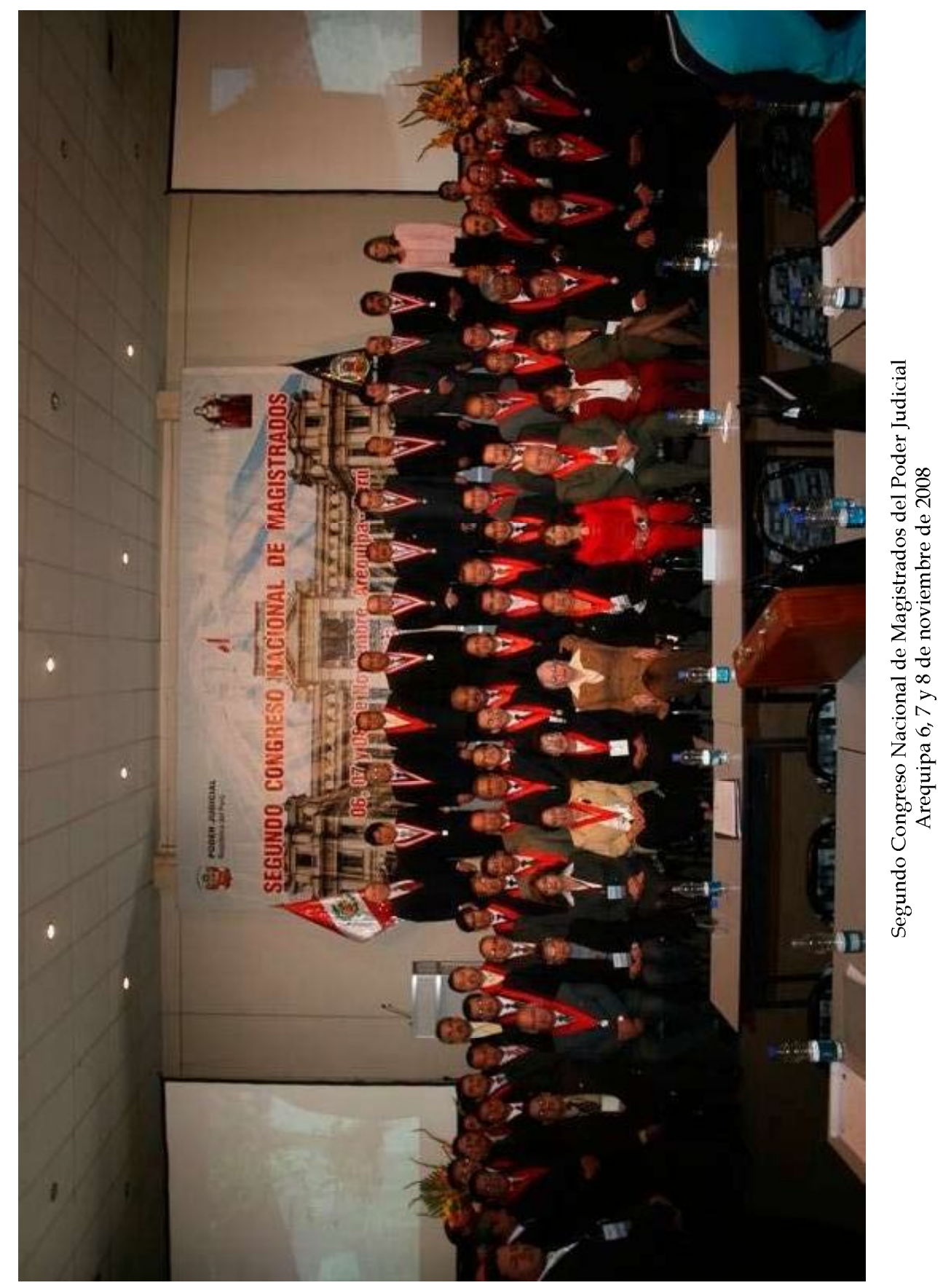

